\title{
Borlói Rudolf: Nyugdíjismeretek
}

\author{
Társadalombiztosítási Könyvtár, Gondolat Kiadó, \\ Budapest, 2018. 392 o.
}

A tágan értelmezett fejlett országok (amelyekbe így beletartozik Magyarország is) nyugdíjrendszereit dominálja a tradicionálisan, ám pontatlanul felosztó-kirovónak is nevezett folyó finanszírozású (pay-as-you-go) nyugdíjrendszer, amely az elmúlt három évtizedben nagyon erős kihívásokkal néz szembe, ezért a jövőben nagyon jelentősen meg kell változnia. E kihívások miatt gondosan meg kell vizsgálni ennek a rendszernek az alapjait, azokat az elveket, amelyekre építve létrehozták és müködtették/müködtetik. Sokak szerint (a jelen sorok szerzői szerint is) e rendszer konstrukciós hibáktól terhelt, így radikális változásokra van szükség. A piaci szereplők és a neoklasszikusnak nevezett közgazdászok a teljes feltőkésítés hívei, mások szerint elegendő volna a paraméterek megfelelő változtatása.

Bármi is a helyes irány, annak meghatározása nem nélkülözheti a jelenlegi rendszer részletes leírását, annak ismeretét, hogy hogyan és miért pont úgy müködik, ahogy. Szükség van a jelenlegi rendszer működésének közérthető dokumentálására és az idevezető történeti - gyakran igencsak kacskaringós - út bemutatására. A magyar nyelvủ szakirodalomban (leszükítve azt a kifejezetten átfogó jellegü, könyvterjedelmủ mủvekre) ilyen nem akad. Vannak ugyan átfogó ismertetések, de azok nagyrészt még a múlt évezredben születtek (Czúcz [1994], Balogh-Szücs [1990], [1998], Balogh [1999]), és sokszor napjainkban már nem releváns problémákra helyezik a hangsúlyt. A 2000-es években is születtek kiváló munkák (Gál szerk. [2003], illetve Simonovits [2002]), de már ezek sem újak - nem a bő 15 év sok, hanem ami azóta történt -, s központi kérdésfeltevéseik is teljesen mások. Kozári [2012] és Matits [2018] ugyan viszonylag újak, de a nyugdijrendszer korai történetére, illetve speciális szegmensének a problémáira koncentrálnak. Holtzer (szerk.) [2010] a magyar nyugdíjszakma egyszeri nagy összefogásával készült, de nem a múltat, nem a müködést próbálja leírni, hanem versengő reformjavaslatokat tartalmaz, akárcsak a BanyárMészáros [2003] könyv is.

Nem járunk jobban akkor sem, ha neves közgazdászok összefoglaló munkáinak magyar fordításait vesszük a kezünkbe. A vaskos, monografikus Stiglitz [2000] és Barr [2009], csupán egy-egy fejezetben foglalkozik a nyugdíjrendszer működésével.

A kézirat első változata 2019. január 14-én érkezett szerkesztőségünkbe.

DOI: http://dx.doi.org/10.18414/KSZ.2019.2.222 
A jelenlegi nyugdíjrendszer működésének viszonylag újabb leírása Novoszáth [2014], illetve Gerencsér [2010]. Az utóbbi szerzője a rendszer magas beosztású működtetője volt. Kiváló könyve azonban inkább ismeretterjesztő münek tekinthető.

Mindezek miatt nagy örömünkre szolgálhat, hogy Borlói Rudolf, az Országos Nyugdíjbiztosítási Főigazgatóság nyugalomba vonult közgazdásza (közgazdasági és statisztikai főosztályának hajdani vezetője), aki a magyar nyugdíjrendszer müködtetésében hosszú időn át részt vett, évtizedes tapasztalatai alapján immár második könyvét publikálta.

Az itt ismertetendő könyv is - mint több fent idézett - a Gondolat Kiadó Társadalombiztosítási Könyvtár sorozatában jelent meg, akárcsak a szerző előző műve (Borlói [2016]). Az új kötet elméleti megalapozásra és a magyar nyugdíjrendszerrel kapcsolatos gyakorlati tudás átadására törekszik, lényegesen részletesebben, mint a korábbi. Ám az előző kötet sem süllyeszthető a könyvtárak mélyére, mert az a szerzőnek a magyar nyugdíjrendszer jövőjével kapcsolatos javaslatait tartalmazza, amelyeket az újban csak igen röviden és a magyar nyugdíjrendszernél szélesebb perspektívában, egyenesen az emberiség sorskérdései közé emelve tárgyal (348-352. o.).

A könyv három, megközelítően azonos terjedelmü részből (ezen belül tíz fejezetből) és a függelékből áll. Az első rész (23-98. o.) - amelynek címe Általános nyugdíjismeretek - három fejezetre oszlik. Az I. fejezet a nyugdíj fogalmát és a nyugdíjrendszer fóbb típusait veszi sorra. Az utóbbit a szakirodalom gyakran tárgyalja, ám az előbbit annyira magától értetődőnek szokás tartani, hogy meghatározásával nem igazán vesződik senki. A szerző rövid definíció megadása után a fogalom rétegeit kibontó tizenegy szempont, kategória alapján (a társadalmitól a makrogazdaságin, a biztosításin és a jogin át a politikaiig) határozza meg a nyugdíj fogalmát. A II. fejezet a nyugdíjrendszer szabályozási területeit tárgyalja, onnan kezdve, hogy hatálya kire terjed (terjedjen) ki, majd sorra veszi a három jogosultsági feltételt (életkor, biztosításban töltött idő, illetve a munkajövedelem és a nyugdíj kapcsolata), s tárgyalja az induló nyugdíj kiszámítására szolgáló nyugdijképletet (nyugdífformulát), a szociális jövedelembiztonság minimális szintjének szabályozását (nyugdíjminimum) és a rendszeres nyugdíjemelés (indexálás) mikéntjét. A III. fejezet a nyugdíj „környezeti feltételeit”, a demográfiai és a foglalkoztatási helyzet alakulását mutatja be.

A második rész (99-205. o.) az elméleti megközelítés felhasználásával értelmezi a mai magyar nyugdíjrendszer gyakorlatát. A IV. fejezet a nyugdíj megállapításáról szól, külön tárgyalva az öregségi és a hozzátartozói (özvegyi nyugdíj, árvaellátás, szülői nyugdíj, baleseti hozzátartozói ellátás) nyugdíjakat. A túlnyomó súlyt képviselö öregségi nyugdíj kiszámításának hat, gondosan elkülönített, szigorúan egymásra épülő szakaszát különbözteti meg. Bár a jelen a 2018-2019 fordulója, de a mai helyzet megértése nem nélkülözheti a közelmúlt - a rendszerváltást közvetlenül megelöző időtől számított három évtized - fejleményeinek bemutatását. Az V. fejezet a nyugdíj megállapítása utáni („folyósítási”) időszak történéseit mutatja be, elsősorban az évi rendszeres nyugdíjemelést (a mai árindexáláshoz vezető utat a hajdani bérindexálástól). Kitér a megállapított nyugdíj kevéssé közismert egyéb változtatási lehetőségeire, továbbá egy rövid életủ ellátásra: a 2003-2009 között létezett (de teljes havi összegben csak 2006-2008-ban fizetett) 13. havi nyugdíjra és a helyébe lépő, növekedési feltételhez 
kötött, lényegesen szerényebb, elöször 2017-ben fizetett nyugdíjprémiumra. A VI. fejezet szintén kevéssé közismert, speciális területeket mutat be: a magyar nyugdíjrendszert érintő nemzetközi ügyeket, a kötelezö nyugdíjbiztosításhoz megállapodás alapján („önkéntesen”) történő csatlakozás lehetőségét, az egyéni számlát, az adategyeztetést, valamint a jogszabályban foglaltaktól a „méltányosság” indokával felfelé való eltérés lehetőségét. A VII. és a VIII. fejezet nyugdíj-üzemgazdasági kérdéseket tárgyal - szintén történeti kitekintéssel (a kezdőpont a Társadalombiztosítási Alap 1989. évi létrehozása, amelyet 1992-ben szétválasztottak Nyugdíjbiztosítási Alapra és Egészségbiztosítási Alapra). A VII. fejezet a finanszírozással és az alapkezeléssel kapcsolatos, a VIII. az ügyviteli-szakigazgatási, illetve a szervezeti-irányítási kérdéseket tekinti át (ismét csak három évtized történelmi perspektívájában).

A harmadik rész (207-292. o.) a nyugdíjrendszer müködési jellemzőit és az azokat mérni képes statisztikai eszköztárat mutatja be. E rész ennek megfelelően két fejezetből áll. A IX. fejezet a különösnek tűnő, de nagyon is találó Rendszer-diagnosztika címet viseli. E hosszú (211-270. o.) fejezet tárgyalja például a helyettesítési ráta fogalmát és számítási módjait (a nyugdijak és bérek viszonyának értelmezése egyáltalán nem triviális) - a nyugdíjrendszerek összehasonlításában e mutatónak különös fontossága van. Itt kerül szóba a nyugdijrendszer pénzügyi-költségvetési tervezése, a járulékbevételek és nyugdíjkiadások mértékére ható tényezők a gazdaság növekedésétől a foglalkoztatás alakulásán át a nyugdíjasállomány összetételének változásáig (úgynevezett cserélődési hatás). E fejezet 7. alfejezetében (255-270. o.) az elméleti (nyugdí)közgazdászokat közvetlenebbül foglalkoztató témák kerülnek tárgyalásra, így a nyugdíjrendszer implicit államadóssága, a korosztályi elszámolás, a belső megtérülési ráta (amely a fizetett járulékok és a cserébe kapott nyugdíjak hosszmetszeti viszonyát mutatja) s végül a nyugdíjrendszer (jövedelem-)átcsoportosító hatását vizsgálja. A záró X. fejezet azokat a statisztikai adatokat és a belőlük képzett (nyugdíj-)mutatókat veszi számba, amelyek az előző fejezetben tárgyalt elemzéshez szükségesek.

A könyv Függelékkel zárul (293-389. o.). Ez sokkal fontosabb, mint a függelékek általában. Első fele a magyar nyugdíjrendszer rövid történetét tartalmazza hat szakaszra bontva (1929 előtti időszak, 1929-1945, 1945-1975, 1975-1988, 1989-1997, 1998-2009), miközben három kitérőt tesz két meg nem valósult, ám komolyan felmerült (alapnyugdíj, különálló közszolgálati nyugdíjrendszer) és egy megvalósult (szépkorúak - 90, 95, 100, 105 stb. évesek - jubileumi juttatása) ötletet felidézve. Hosszabban ismerteti a hetedik korszakot, a 2010-től kezdődő és napjainkban is tartó időszakot, amelynek legnagyobb fontosságú lépése az 1998-ban létrehozott második pillér felszámolása volt. Fontos lépése volt továbbá a rokkantnyugdij-rendszer nyugdíjrendszeren kívülre helyezése (és a „rokkantnyugdíj” fogalmának szótárból való törlése), az úgynevezett svájci indexálásról az árindexálásra történő áttérés (ami az évtized végi dinamikus béremelkedés ismeretében igencsak kedvezőtlenül érintette a nyugdíjasokat), a korai (nyugdíjkorhatár előtti) nyugdíjba vonulás lehetőségének felszámolása (leszámítva a 2011-ben bevezetett „nők 40” programot). Ez összességében a nyugdíjasok felől nézve jelentős megszorítás, az államháztartás felől nézve a nyugdíjrendszer fenntarthatósága érdekében tett lépések, miközben a szociális hozzájárulási adóvá átnevezett foglalkoztatói nyugdíjbiztosítási 
és egészségbiztosítási járulék 2017-ben megkezdett (27 százalékról 22 százalékra, 2018-ban 19,5 százalékra) csökkentése rontja a fenntarthatóságot, de a kormány szándéka szerint növeli a versenyképességet.

A Függelék - $s$ talán az egész könyv - legfontosabb része A könyv fogalomhasználata (353-389. o.) címet viselő összeállítás. E részben harmadfélszáz nyugdíjszakmai, illetve azzal összefüggésben is használt fogalom, terminus technicus rövid magyarázata szerepel - utalással a könyv azon helyére, ahol azok részletesebben kifejtésre kerültek, $\mathrm{s}$ - szükség esetén - utalással kapcsolódásaikra.

Mi is ez a könyv? A szerző tudatosan tankönyvként írta meg (s mint ilyen, az egyes tárgykörök után ellenőrző kérdéseket tartalmaz), de talán szerencsésebb volna a magyar nyugdíjrendszert leíró kézikönyvként és lexikonként értelmeznünk, hiszen a szerző tárgyát nagyon sokoldalúan, enciklopédikus teljességre törekedve közelítette meg. Aki ezek után a magyar nyugdíjrendszerre, tágabban az állami/társadalombiztosítási rendszerekre kíváncsi, annak minden más elött ezt a könyvet kell kézbe vennie, illetve keze ügyében tartania. A megcélzott olvasóközönség nem csupán a nyugdíjügy iránt személyes érintettségük miatt érdeklődő iskolázottabb közönség (a közgazdasági végzettség előny, de nem követelmény, az érettségi bizonyítvány azonban nehezen nélkülözhető), a szakújságírók, közgazdászhallgatók, a tárggyal kapcsolatba kerülő kormánytisztviselök stb. Az olvasónak mindössze az irodalomjegyzéknél támad bizonyos hiányérzete, hiszen az eléggé visszafogott, mindössze egyoldalnyi (391-392. o.).

Befejezésül említést érdemel a gondos könyvészeti kivitelezés: e sorok írói keresve se találtak betűelütéseket, hibás központozást, elválasztási hibákat, s a táblázatok szerkesztése is nagy gonddal történt, ami majdhogynem kivételesnek mondható. A könyv jó stílusban, jól olvashatóan van megírva, s terjedelme ellenére sem túlírt, hangneme példaértéküen visszafogott. A szerző elfogulatlanul, méltányosan szól az övével nem megegyező, esetleg szögesen ellentétes nézőpontokról, megközelítésekről. Az irodalomjegyzék talán lehetne egy kicsit hosszabb, hiszen egy tankönyv/szakkönyv célja az is, hogy az érdeklődőknek további olvasnivalókat tanácsoljon.

Elmondható ugyanakkor, hogy alapkönyv született. Annak a szerzőnek, aki e tárgynak újból nekifut, akarva-akaratlanul Borlói Rudolf Nyugdíjismeretek címü könyve lesz a kályha, amihez saját könyvét mérheti, és mások is mérni fogják.

\section{Hivatkozások}

BALOGH GÁBOR [1999]: Bevezetés a társadalombiztosítás gazdaságtanába. Osiris Kiadó, Budapest, 252 o.

BALOGH GÁBOR-SzỨCs LÁszLó [1990]: Társadalom biztosítás nélkül. Gyorsuló idő. Magvető Kiadó, Budapest, $184 \mathrm{o}$.

BALOGH GÁBOR-SzỨCs LÁszLó [1998]: Alkalmazott társadalombiztosítás-tan. Osiris Kiadó, Budapest, 355 o.

BANYÁR JózSEF-MÉsZÁros JózSEF [2003]: Egy lehetséges és kívánatos nyugdijrendszer. Gondolat Kiadó, Budapest, 238 o.

BARR, N. [2009]: A jóléti állam gazdaságtana. Akadémiai Kiadó, Budapest, 634 o. 
BoRlói Rudolf [2016]: Gondolatok a magyar nyugdíjrendszerről. Társadalombiztosítási Könyvtár. Gondolat Kiadó, Budapest, 201 o.

Czúcz Oттó [1994]: Az öregségi nyugdíjrendszerek. A nyugdíjak jogi szabályozásának alapvető kérdései. Közgazdasági és Jogi Könyvkiadó, Budapest, 220 o.

GÁL RóBERT Iván (szerk.) [2003]: Apák és fiúk és unokák. Osiris Kiadó, Budapest, 210 o.

GERENCSÉR LÁszLó [2010]: Ismerje meg a nyugdíjrendszert! Tanulmányok kezdőknek, haladóknak és szakértőknek. Urbis Könyvkiadó, Szentendre, 256 o.

Holtzer Péter (szerk.) [2010]: Jelentés a Nyugdíj és Időskor Kerekasztal tevékenységéről, Miniszterelnöki Hivatal, Budapest, 399 o.

KozÁri Monika [2012]: A nyugdíjrendszer Magyarországon Mária Teréziától a második világháborúig, Társadalombiztosítási Könyvtár. Gondolat Kiadó, Budapest, 366 o.

Matits Ágnes [2018]: A magyar nyugdíjpénztárakról. Válogatott írások az elmúlt negyedszázadból. Társadalombiztosítási Könyvtár. Gondolat Kiadó, Budapest, 348 o.

Novoszáth PÉTer [2014]: A társadalombiztosítás pénzügyei. Tankönyvkiadó, Budapest, 244 o.

Simonovits András [2002]: Nyugdíjrendszerek: tények és modellek, Typotex Kiadó, Budapest, 226 o.

STIGLITZ, J. E. [2000]: A kormányzati szektor gazdaságtana, KJK-Kerszöv Jogi és Üzleti Kiadó Kft., Budapest, 748 o.

Banyár József-Németh György

Banyár József fötanácsadó, ONYF, címzetes egyetemi docens, BCE Biztosítási Oktató- és Kutatócsoport (e-mail: banyar.jozsef@onyf.hu).

Németh György szociológus-közgazdász, MÁK. 